\title{
Relation Benefit Implication for Repeating Order through Online Sales Application case study Batik SMEs in East Java
}

\author{
Muslichah Erma Widiana ${ }^{1}$ \\ ${ }^{I}$ (Management Department,Bhayangkara University, Surabaya, Indonesia)
}

\begin{abstract}
Strategy relational benefits, when viewed from the perspective of Customer Relationship Management is a strategy to facilitate the implementation of Customer Relationship Management strategy to become business actions to respond to the behavior of actual and potential customers. Information technology also provides many benefits and services for customers such as the benefits of the trust in the form of selfconfidence and reduced anxiety (Rebecca and Kevin P. Gwinner, 2003[1]). The use of information technology also provide time benefits which is saving the time to visit or view the product and also selling the product at the same time (Yujong Hwang and Dan J.Kim, 2007[2]).The sampling method used in this study is proportional cluster random sampling. The samples is from the online customer of the batik product in East Java from February to May 2013. Analysis of the data in this study are using Structural Equation Modelling (SEM). Based on the results of research on that confidence can benefit significantly influence the satisfaction, confidence benefits significantly influence usage intention, social benefits significantly influence satisfaction, social benefits significantly influence usage intention, special treatment benefits significantly influence satisfaction, special treatment benefits significantly influence usage intention, satisfaction significant effect on usage intention. Keywords -confidence benefits, social benefits, special treatment benefit, satisfaction and usage intention.
\end{abstract}

Submitted date 11 June 2013

Accepted Date: 17 June 2013

\section{INTRODUCTION}

Business leaders will take advantage of the new way that is based on the increasing speed of information. A new way was not merely due to the use of technology for itself, but its use to reshape the company gait. To get the benefits of technology, business leaders must modernize information technology processes within their organization (Ma'ruf, 2004[3]).

Business strategy with Customer Relationship Management (CRM) related to other business strategy such as technology usage and that kind of relation often called as Relationship Benefit (RB). Technology Acceptance Model (TAM) usually only provide information or general result about the interest and behavior of users in term of information technology adaptation and usage. RB strategy is a long-term strategy between the consumer and the service provider to give several benefit to the customer.

On the other hands, information technology also give several benefit to the customer such as convenience and this also enhance the trust for customer in the form of self-confidence and anxiety reduction (Rebecca and Kevin P. Gwinner, 2003[1]). Personal trust from the customer to the online service provider is one of the social benefits that is built from the benefits of information technology (Yujong Hwang and Dan J.Kim, 2007[2]). The use of information technology can provide special benefits (special treatment benefit) the form of timesaving to visit several online websites that sell products at a time (Rebecca and Kevin P. Gwinner, 2003[1]). Confidence benefit as reduced feelings of anxiety turned into confidence, and trust in the service providers can improve customer satisfaction in the use of information technology (Gwinner et al., 1998[4]; Thorsten et al., 2002[5]; Rebecca and Kevin P. Gwinner, 2003[1]; Tracey and Timothy, 2010[6]). Consumer confidence to remain in touch with online service providers can also increase the intensity of the use of information technology as a means of financial transactions (usage intention) (Thorsten et al., 2002[5]; Rebecca and Kevin P. Gwinner, 2003[1]; Tracey and Timothy, 2010[6]). Social benefit is a benefit received by the customer because of the emotional relationship with a particular service provider can increase satisfaction (Gwinner et al., 1998[4]; Price and Arnould's 1999[7]). Social benefit directly affect the intensity of use (usage intention) of online shopping (Thorsten et al., 2002[5]; Tracey and Timothy, 2010[6]). Special treatment benefit also can affect Satisfaction, consumer feel satisfied with the purchase made by the company (Thorsten et al., 2002[5]). Giving discounts can also affect future repurchase (usage intention) (Thorsten et al., 2002[5]; Rebecca and Kevin P. Gwinner, 2003[1]; Tracey and Timothy, 2010[6]).

Batik is one of Indonesia's unique product. Over decade Indonesian batik confronting a tough competition with similar product from Malaysia, Thailand, Singapore and China. This condition is worsen because they used more advance technology and able to produce much quicker and cheaper price. 
According to Ministry of Trade Republic Indonesia, number of Indonesian batik handicrafts business or we called Small and Medium Enterprises (SME) is around 48.287 unit. Thus the number of employment is around 792.300 person, this equivalent to Rp 2.9 trillion productions value and the export value is around US\$ 110 million. This batik handicrafts industry are scattered over 17 provinces across nation. Furthermore, the young generation nowadays tend to love their own batik motif from their own area. This tendency is good for the batik industrials development also will stimulate the export potential to foreign countries. To reach the global market the use of technology is necessary; especially the form of e-commerce is required for SMEs to promote their product. This technology can eliminate the geographical boundaries, and not only to promote it but also enable transaction through online shopping.

Based on the background as described above, raises several question for this research study, as follows:

1. Is confidence benefit increase the customer satisfaction who make online purchasing for batik SMEs in East Java?

2. Is confidence benefit increase the consumer usage intention who make online purchasing for batik SMEs in East Java?

3. Is Social benefits increase consumer satisfaction who make online purchasing for batik SMEs in East Java?

4. Is Social benefit also increase the consumer usage intention who make online purchasing for batik SMEs in East Java?

5. Is special treatment benefit increase the consumer satisfaction who make online purchasing for batik SMEs in East Java?

6. Is special treatment benefit also increase the consumer usage intention who make online purchasing for batik SMEs in East Java?

7. Is satisfaction increase the consumer usage intention who make online purchasing for batik SMEs in East Java?

\section{LITERATURE REVIEW}

\section{Customer Relationship Management}

Customer relationship management (CRM) is the process of obtaining, retaining and developing profitable customers. Customer relationship management requires a clear focus on value-added attributes of the services to our customers and create customer loyalty. Customer relationship management consists of five main elements, namely strategy, segmentation, technology, processes, and organization (Husein, 2000[8]). An enterprise-wide business strategy designed to optimize profitability, revenue and customer satisfaction by organizing company based on customer segments, strengthen customer satisfaction behavior, and linking processes from customers to suppliers.

Key CRM technology provides a number of benefits, including a better understanding of the customer, the customer's increased access, more effective customer interaction and integration between the functions of customer channels and back-office. CRM application fields include technology-enabled selling, service and customer support, and technology-enabled marketing. Customer relationship management is a core business strategy that integrates internal processes and functions, and external networks to create and deliver value to targeted customers in order to gain profit. Customer relationship management is supported with high quality customer data and information technology facilitated (Buttle, 2004[9]).

\section{Technology Acceptance Model}

The main goal Technology Acceptance Model (TAM) as stated by Davis is to explain the factors that influence the acceptance of information technology with a broad range of information technology and population of users. Actual system usage is determined by behavioral intention to use, which in turn is determined along with the attitude towards the use and perceived usefulness.

Through a number of literature known TAM can be applied in various situations. Obtaining an understanding of the condition before will enable the development of design in a more meaningful research and training interventions to improve user acceptance and use of technology. Furthermore, the inclusion of external variables as proposed in the TAM (Davis, Bagozzi and Warshaw, 1989[10]).

\section{Relational Benefit}

Relational Benefit is defined as the benefits derived from the consumer long-term relationship of the main services (Gwinner et al., 1998[4], Lovelock et al. 2001[11]) defines relational benefits as the total number receiving benefits due and still use the services of a service provider is reduced by the amount of the total cost either financially or not. Profits were the result of long-term engagement with service companies

\subsection{Confidence Benefit}


Confidence benefit is the consumer benefits by reducing uncertainty (Gwinner et al., 1998[4]). Confidence Benefit indicator as mention (Gwinner et al., 1998[4]) is: (1) reduced anxiety and (2) trust / confidence

\subsection{Sosial Benefit}

Social benefits are benefits received by customers as a result of the relationship with the service provider specific. In addition to the benefits received in the delivery of core services, consumers also receive benefits in the form of friendship that takes place between customers and service providers (Gwinner et al., 1998[4]). Benefits of social indicators developed by Gwinner et al., (1998[4]) is: (1) Fraternization,(2) friendship, and (3) personal recognition.

\subsection{Special Treatment Benefit}

Special treatment benefit is a special benefit received by consumers in the form of extra attention or personal recognition, and specialized services that are not available to other customers (Gwinner et al., 1998 [4]). Special treatment benefit in the exchange relationship marketing has been alluded to in some literature (Barlow 1992[12]; Hakansson 1982[13]). Crosby (1995[14]) proposed upgrade of core services while Berry (1995[15]) proposed an additional benefit as a way to provide benefits to customer's special treatment as a form of appreciation to consumers.

Gwinner et al., (1998[4]) give some indicator for Special treatment benefit which is: (1) preferential treatment, (2) additional service or considerations, (3) history development. (4) discount, (5)time saving.

\section{Satisfaction}

Usmara (2003[16]) states Satisfaction is the comparison between the performance earned comparisons with standard expectations, ideal, competitors, marketers promise and norms. Satisfaction and dissatisfaction is a comparison between the performance of pre-purchase expectations and perceptions of performance received by the consumer after purchase. Satisfaction according to Kotler (2002[17]) is the level of one's feelings after comparing the performance or results that he felt with his expectations. Indicator in Satisfaction universally according to Dutka (1995[18]) is: (1)Attributes related to the product, (2)Attributes related to service, (3)Attributes related to purchase.

\section{Usage Intention}

Definitions usage intention by Davis et al., (1989[10]) is a behavioral tendency to keep using a technology and a desire to motivate other users. Of internet usage research Grace et al. (2009[19]) defines, the usage intention is the intention of re-use is primarily aimed at individuals to make purchases online through the internet. Intention to always use the online purchase and recommend purchases online (Edwin Cheng et al., 2005[20]; Jiun Sheng, 2007[21]). Edwin Cheng et al. (2005[20]) developed an indicator usage intention as follows: (1) Always use internet banking for banking purposes, (2) use internet banking to complete banking transactions, (3) my own use internet banking to complete my banking transactions itself.

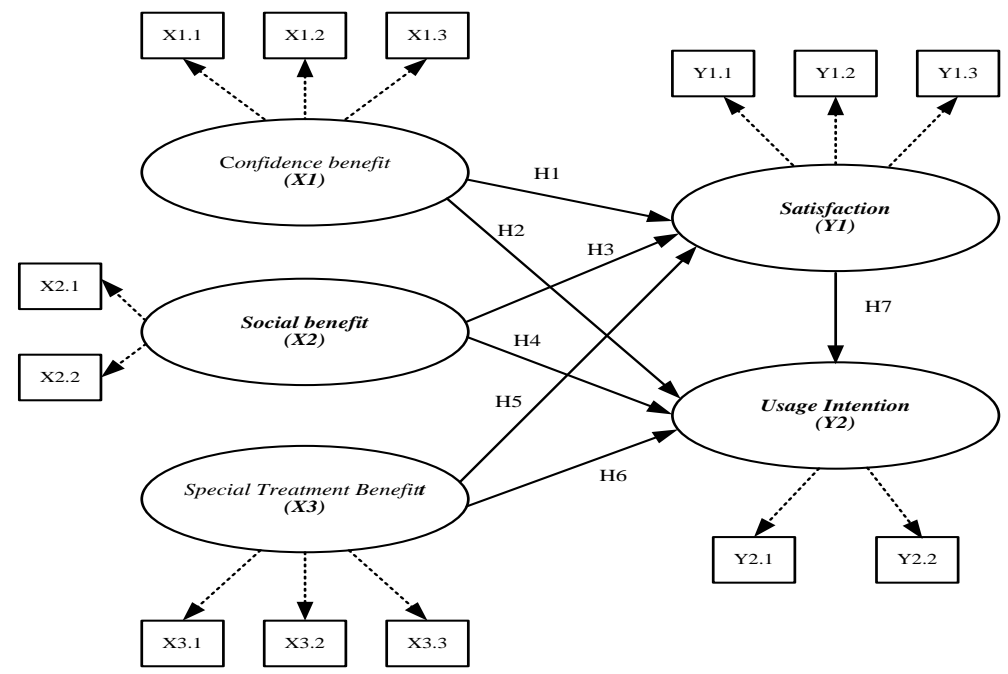

Fig. 1. Conceptual framework

\section{Research Type}

III. RESEARCH METHODOLOGY 
This research is explanatory research that aim to clarify the influence of causal relationships among the variables in the research problems that have been clearly identified (Zigmund, 1997: 39-41[22]). The type of data in this study is a cross-section that is collecting data at a particular time is not a long-term (longitudinal).

\section{Sampling}

The sampling technique is using proportional random sampling. Samples taken from customer population group of online shopper in SMEs batik production in East Java. The sample is taken during period February - May 2013 on several cities in East Java such as Sidoarjo, Jombang, Malang, Bangkalan, Surabaya, and Pamekasan. Due to the large population of sample, in this research only taken 180 data from 2.943 data. This is in accordance with the rules of SEM that samples taken ranged 100-200. The number of samples is determined by the formula (1):

$\mathrm{ni}=\frac{N i}{N} X n$

...p.

With criteria:

a. Consumen buy online to SMEs which produce batik.

b. $\quad$ Buy more than once to that SMEs

\section{Research Variable}

As mention before there is five latent variable which is: social benefit (X1), confidence benefit (X2), special treatment benefit (X3), satisfaction (Y1) and usage intention (Y2).

\section{Exogenous Variable}

Which is a variation of the variable value will affect the variation of the value of the other variables in the model and never influenced by any other variable. In this study the one that considered as exogenous variable is: social benefit (X1), confidence benefit (X2), and special treatment benefit (X3).

\section{Endogenous Variable}

Which is a variation of the variable value depends on the variation of the value of one or more other variables. For the endogenous variables in this study, there are two kinds, which is:

\section{Intervening endogenous variable}

In this research, the intervening endogenous variable is Satisfaction (Y1)

\section{Dependable endogenous variable}

In this research, the dependable endogenous variable is Usage Intention (Y2).

Furthermore, please refer to Table 1. For more explanation about the variable and research indicators which consisting: Relational Benefit and Marketing outcome.

Table 1. Variable and Research Indicator

\begin{tabular}{|c|c|c|c|}
\hline Variable & Indicator & $\begin{array}{l}\text { Num } \\
\text { ber of } \\
\text { items }\end{array}$ & $\begin{array}{l}\text { supporting } \\
\text { literature }\end{array}$ \\
\hline \multirow[b]{2}{*}{$\begin{array}{l}\text { Confidence benefit } \\
\text { (X1) }\end{array}$} & Reducing anxiety (X1.1) & 3 & \multirow{2}{*}{$\begin{array}{l}\text { Gwinner, } \\
(1998[4]) \\
\text { Thorsten, } \\
(2002[5])\end{array}$} \\
\hline & Increase Confidence (X1.2) & 3 & \\
\hline \multirow[b]{2}{*}{$\begin{array}{l}\text { Social benefit } \\
\text { (X2) }\end{array}$} & Fraternization $(\mathrm{X} 2.1)$ & 2 & \multirow{2}{*}{$\begin{array}{l}\text { Gwinner, } \\
\text { (1998[4]) } \\
\text { Thorsten, } \\
(2002[5])\end{array}$} \\
\hline & Personal Recognition (X2.2) & 2 & \\
\hline \multirow{3}{*}{$\begin{array}{l}\text { Special treatment } \\
\text { benefit } \\
\text { (X3) }\end{array}$} & Additional usage (X3.1) & 3 & \multirow{3}{*}{$\begin{array}{l}\text { Gwinner, } \\
(1998[4]) \\
\text { Thorsten, } \\
(2002[5])\end{array}$} \\
\hline & Service history (X3.2) & 4 & \\
\hline & Sale prices $(\mathrm{X} 3.3)$ & 2 & \\
\hline \multirow[b]{3}{*}{$\begin{array}{l}\text { Satisfaction } \\
\text { (Y1) }\end{array}$} & attributes related to the product (Y1.1) & 7 & \multirow{3}{*}{$\begin{array}{l}\text { Thorsten } \\
(2002[5]), \\
\text { Rebecca } \\
(2003[1]), \text { Joon } \\
\text { Hong } \\
(2006[21]), \\
\text { Tracey } \\
(2010[6])\end{array}$} \\
\hline & attributes related to service (Y1.2) & 3 & \\
\hline & attributes related to purchase (Y1.3) & 3 & \\
\hline \multirow{2}{*}{$\begin{array}{l}\text { Usage Intention } \\
\text { (Y2) }\end{array}$} & Usage Intention (Y2.1) & 3 & \multirow{2}{*}{$\begin{array}{l}\text { Davis } \\
(1989[10])\end{array}$} \\
\hline & Recommendation (Y2.2) & 3 & \\
\hline
\end{tabular}


IV.

RESEARCH ANALYSIS

Analysis used to answer the hypotheses in this research is using Structural Equation Model (SEM) using Amos 7.0 program package and SPSS version 15.0. Hypothesis testing is done by looking at the path coefficients and $\mathrm{p}$ value at the 0.05 level. Further detail about this testing is describe on table 2 :

Table 2 Result of Structural Model for Online Shopping Customer

\begin{tabular}{|c|c|c|c|c|c|}
\hline Number & Hypothesis & $\begin{array}{l}\text { Line } \\
\text { Coefficient }\end{array}$ & C.R. & $\begin{array}{l}\text { p- } \\
\text { value }\end{array}$ & $\begin{array}{l}\text { Hypothesis Testing } \\
\text { Results }\end{array}$ \\
\hline 1. & $\begin{array}{l}\text { Confidence Benefit (X1) to } \\
\text { Satisfaction (Y1) }\end{array}$ & 0.544 & 6.105 & 0.000 & $\begin{array}{l}\mathrm{H} 1 \quad=\quad \text { towards } \\
\text { positive } \quad \text { and } \\
\text { significant effect }\end{array}$ \\
\hline 2. & $\begin{array}{l}\text { Confidence Benefit (X1) to } \\
\text { Usage Intention (Y2) }\end{array}$ & 0.433 & 4.053 & 0.000 & $\begin{array}{l}\mathrm{H} 2 \quad=\quad \text { towards } \\
\text { positive } \\
\text { significant effect }\end{array}$ \\
\hline 3. & $\begin{array}{l}\text { Social Benefit (X2) to } \\
\text { Satisfaction (Y1) }\end{array}$ & 0.417 & 5.458 & 0.000 & $\begin{array}{l}\mathrm{H} 3 \quad=\quad \text { towards } \\
\text { positive } \quad \text { and } \\
\text { significant effect }\end{array}$ \\
\hline 4 & $\begin{array}{l}\text { Social Benefit (X2) to } \\
\text { Usage Intention (Y1) }\end{array}$ & 0.545 & 4.896 & 0.000 & $\begin{array}{l}\mathrm{H} 4 \quad=\quad \text { towards } \\
\text { positive and } \\
\text { significant effect }\end{array}$ \\
\hline 5 & $\begin{array}{l}\text { Special Treatment Benefit } \\
\text { (X3) to Satisfaction (Y1) }\end{array}$ & 0.500 & 4.431 & 0.000 & $\begin{array}{l}\mathrm{H} 5 \quad=\quad \text { towards } \\
\text { positive } \quad \text { and } \\
\text { significant effect }\end{array}$ \\
\hline 6 & $\begin{array}{l}\text { Special Treatment Benefit } \\
\text { (X3) to Usage Intention } \\
\text { (Y1) }\end{array}$ & 0.590 & 5.518 & 0.000 & $\begin{array}{l}\text { H6 = towards } \\
\text { positive } \quad \text { and } \\
\text { significant effect }\end{array}$ \\
\hline 7 & $\begin{array}{l}\text { Satisfaction (Y1) to Usage } \\
\text { Intention (Y2) }\end{array}$ & 0.764 & 5.455 & 0.000 & $\begin{array}{lr}\mathrm{H} 7 \quad=\quad \text { towards } \\
\text { positive } \\
\text { significant effect }\end{array}$ \\
\hline
\end{tabular}

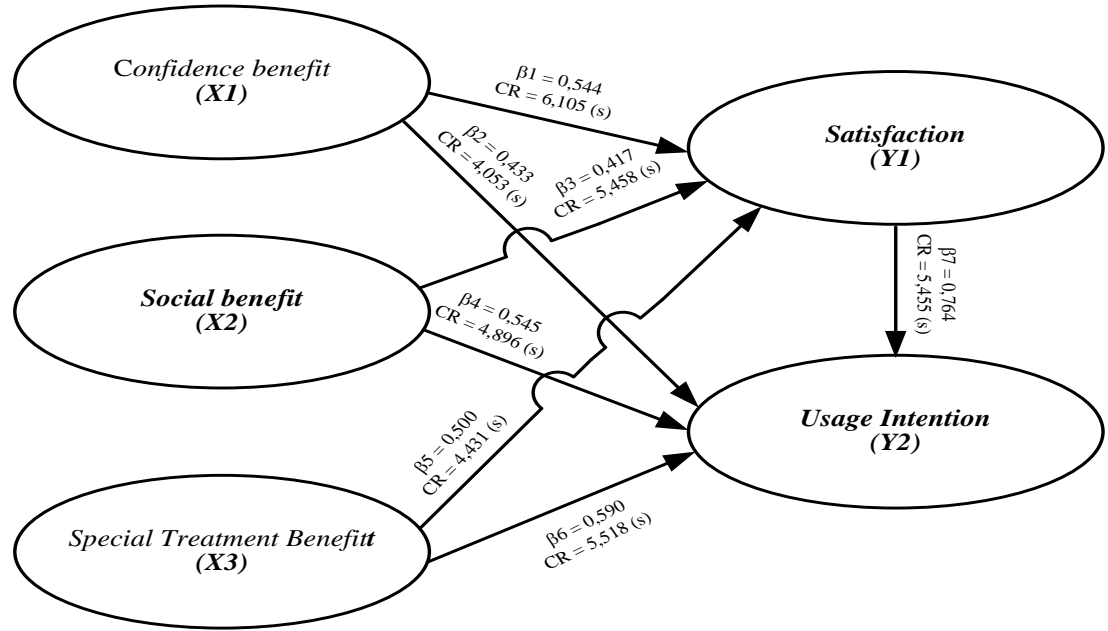

Fig 2. Structural Equation Model Analysis Result

\section{Influence of Confidence Benefit against Satisfaction}

DISCUSSION

Results of this study declare that the confidence benefit significantly influence satisfaction, because the critical ratio value of 6.105 is greater than 1.96. This may imply that changes in confidence benefit significantly influence changes in satisfaction. Results of this study support the findings of Gwinner et al., (1998[4]); Thorsten et al., (2002[5]); Rebecca and Kevin P. Gwinner (2003[1]); Tracey and Timothy (2010[6]) who expressed confidence benefits as reduced feelings of anxiety changed to confidence, and confidence in service providers can increase satisfaction in the use of information technology. Anderson (1998[23]) who expressed the belief and confidence in an exchange has been found to have a positive impact on the level of satisfaction in the relationship between producers and buyers. Solimun (2006) expressed the hope has a direct influence on satisfaction because consumers tend to assimilate the satisfaction level to match the level of expectation to reduce dissatisfaction. The results support the research Rebecca Yen (2003[1]). This can be explained as follows. On research Rebecca Yen (2003[1]), the influence of confidence benefit only assessed based on the respondents' confidence in the security of online transactions to the satisfaction of time for services using a travel agent (only one indicator only). 


\section{Influence of Confidence Benefit against Usage Intention}

Results of this study declare that the confidence benefit significantly influence usage intention, because the critical ratio value of 4.053 is greater than 1.96 . This means that changes in confidence benefit significantly influence changes in usage intention, because intention to make usage more respondents account for the timely delivery of products to consumers and compliance orders. Due to the timeliness of the delivery of other people who recommended more confident to make a purchase at the online batik shop. The results support the theory of Berry (1995) which states trust in a relationship reduces uncertainty and vulnerability, because customers develop trust in suppliers based on their experience with service, has good reason to be in a relationship. Bitner (1995) asserted that the staunch meeting as an opportunity for service providers to build confidence in order to increase customer loyalty. Research Thorsten et al., (2002[5]); Rebecca and Kevin P. Gwinner (2003[1]); Tracey and Timothy (2010[6]) which reveals consumer confidence to remain in touch with online service providers can also increase the intensity of use of information technology.

\section{Influence of Social Benefit against Satisfaction}

Based on the results of SEM analysis is known that there are significant correlation between social benefit to the satisfaction, because the critical ratio value of 5.458 is greater than 1.96 . This means the higher the social benefit, the higher the satisfaction. The results support Gwinner et al., (1998[4]); Price and Arnould's (1999[7]) which revealed social benefit is a benefit that is received by the customer because of their emotional relationships with certain service providers can increase satisfaction. Therefore, it is important for companies to focus how the company treats its customers and how to foster positive feelings within yourself customers. Creates positive emotions and feelings are very important in building relationships. The lack of emotional satisfaction than making a mechanical activity that has no real strong reason to be satisfied.

Goodwin (1997[25]), Gerald (1996[26]) suggest a positive social benefit associated with the company's commitment to customers. Reynolds and Beatty (1999[27]) social benefit, as the interaction between customers and employees is central to customer perceptions of the quality on some services. Gremler and Gwinner (2000[28]), namely employee relationship with the customer, is a concept related to social benefits, are significantly related to customer satisfaction. Price et al., "Commercial friendship" as a key element of social benefit and satisfaction. Based on the theory of CRM (Buttle, 2004[29]) impact on satisfaction social benefit is the scope of the application is to be strategic, customer-oriented customers, conform to the wishes of the customer, or focused on the customer

\section{Influence of Social Benefit Against Usage Intention}

Results of this study demonstrate that the social benefit also significantly influence satisfaction, because the value of 4,896 critical ratio greater than 1.96. This means that the higher the social benefit also higher the usage intention. The results support the research Thorsten et al., (2002); Tracey and Timothy (2010) social benefits affect the intensity of use (usage intention) online spending. Researchers Gremler (2000[28]) concept of social relationships such as love, tolerance, and respect have been found and influential in the development of usage intention.

Social relationships that can be developed through respect and prefer the customers can be done by the company to truly understand the needs of the customer. To make customers make repeat purchases, more than just giving customers a quality product, at an attractive price, but companies should also look at the customer desires when interacting with the company. Customers want to be appreciated and cared seriously by the company.

The results support previous research by Price and Arnould (1999[7]), Reynolds and Beatty (1999[27]) that there is a strong relationship between the social benefit of the customer relationship and service providers with usage intention. Berry (1995[15]) suggests that the social bonds between customers and employees can be used to encourage the usage intention. Oliver (1999[30]) stated that customers who are part of the social organization is more motivated to maintain loyalty to the organization.

\section{Infulence of Special Treatment Benefit against Satisfaction}

Based on the results of SEM analysis note that the special treatment benefit significantly influence satisfaction, because the critical ratio value of 4.431 is smaller than 1.96 . This means special treatment benefit changes affect changes on satisfaction. Result of this study supports the findings of Reynolds and Beatty (1999[27]), declared Special Treatment Benefits can be considered as part of the performance of the service itself, and thus, the benefits received from the Special Treatment Benefit is expected positively affect Satisfaction with the service. Thorsten (2002[5]) prove that the Special Treatment Benefit may affect Satisfaction. On research Rebecca Yen (2003[1]) using the indicator variable special treatment, special price given by the company travel agency for students who travel frequently affect satisfaction with the services provided by the travel agency. Research Rebecca Yen (2003[1]) using only one indicator of 
satisfaction is related to satisfaction with services (related to service). This study uses three indicators are related to service satisfaction (related to service), relating to the product (related to product) and related to the purchase (related to purchase).

Satisfaction with the suitability of the offered price of batik products with product quality (indicator on variables related to product satisfaction) are affected by the benefits received by consumers with service development by companies to consumers in a personal form of motifs, color or type of material is preferred by consumers (historical indicators services on special treatment). However, customer satisfaction is more influenced by the discount given by the company at the special price of batik.

\section{Influence of Special Treatment Benefit against Usage Intention}

Results of this study declare that the special treatment benefits influence on usage intention, because the critical ratio value of 5.518 is greater than 1.96 . This may imply the higher the special treatment benefit, the higher the usage intention.

The results support the research Reynolds and Beatty (1999[27]) and Thorsten (2002[5]). An organization provides additional benefits specific types of treatment (e.g., the economic cost savings or service customized) emotionally or cognitively able to increase the barriers to switching and can result in improved Usage Intention (Changki, 2007[31]). The results Thorsten et al., (2002[5]); Rebecca and Kevin P. Gwinner (2003[1]); Tracey and Timothy (2010[6]) showed that the special treatment benefit effect on usage intention, can also affect the provision of discounts on future purchases back (usage intention)

To improve customer barriers to switching, batik online companies have to make the customer feel comfortable when dealing with the company. When a customer makes a life chat through yahoo messenger, make customers like to know the staff of the company. Through this way, the company has developed the staff trust arising frequent occurrence of familiarity.

Long-term loyal customers is a source of free advertising. They became ambassadors for the company. Recommendations from friends and family is a strong endorsement for the company's products and services and are often taken more seriously or more trustworthy than the message delivered by the company itself. When the loyal customers who recommend a product or service to others, the company gained new revenue potential and the opportunity to build more customer relationships. Loyal customers are listed in the database and employees know the customers well, so they are easily serviced because it is known by the company, also known customer needs and can be easily fulfilled, customer needs can be anticipated if the customer specifically recognized by the company

\section{Influence of Satisfaction against Usage Intention}

Results of this study declare that satisfaction affect the usage intention, because the critical ratio value of 5.455 is greater than 1.96. It can mean the higher the satisfaction, the higher the usage intention. Satisfaction with the flexibility to choose batik products are offered online, service satisfaction can increase intention to use online media to find a new motif batik products (usage intention), this can increase the usage intention in the another batik product shop. This also to improve the effect of word of mouth from the closest friends to other in order to share the feel of satisfaction as perceived.

The results support the research Thorsten et al., (2002[5]). Changki Kim (2007[31]) that the success of information technology is determined by how the development of these technologies that can contribute to the satisfaction of the users. The user of the technology can be individuals or organizations, to make a positive contribution to the user can influence the intensity of use of these technologies this is can be seen by the more frequent and the length use of information technology. Yujong (2007[2]) prove to the satisfaction of using selfservice technology, among others, to buy a plane ticket, using banking facilities may affect the intensity for reuse self-service technology in the future. Fandy Tjiptono (1997:24[32]) that loyal consumers will also bring in new customers as loyal consumers will submit a recommendation from positive word of mouth to others.

\section{RESEARCH FINDING}

The empirical finding in this research can be described as follows:

1. Result of this study shown that marketing outcome is influence by Relation Benefit. Result of this study expand the previous result of the research done by Thorsten and Gwinner (2002[5]), Rebecca Yen (2003[1]) and Tracey (2010[6]). The use of technology for online sales with ease and usefulness can be used to increase profit received by customers on long term outcomes as well as fostering relationship can be used to improve customer satisfaction and repeating purchase of online product.

2. This research was based on the theory of Customer Relationship (Buttle, 2004[29]) which includes three operational scope of the assessment, strategic and analytical. Customer relationship management is strategically focused on efforts to develop a culture of customer-oriented business or customer-centric. This culture is intended to win the hearts of consumers and maintain their loyalty by creating and delivering 
value to customers who outperform competitors (Buttle, 2004[29]). Customer-oriented strategies can be developed through relational benefits, relational benefits as a way to provide customer oriented with optimum benefits to customers through increased confidence (confidence benefits), the development of friendships (social benefits) and the provision of special services (special treatment benefits). The third strategy is pursued to improve the online buyback or increase the product recommendations to other customers.

\section{CONCLUSION}

follows:

Based on the result of data analysis and discussion, the conclusion of this study can be described as

1. Research result shown that confidence benefit increasing satisfaction. Satisfaction from the freedom of browsing batik product, which offered through online shopping, is correlated to the benefit received by customer (confidence benefit) from the quality assurance given by the seller that the online product have a good quality.

2. The result shown that confidence benefit increasing usage intention. Intention of using online media either buying or browsing batik product, is related to the benefit which received by customer from the reputation of the seller.

3. From the research result also shown, that social benefit is significantly increasing the satisfaction. This result support the previous research done by Reynolds and Beatty (1999[27]), Gremler and Gwinner (2000[28]). To maintain the relation with the online customer, the seller can provide a live chat facility such as using yahoo messenger.

4. Research result shown social benefit increasing usage intention. This result support previous research by Goodwin and Gremler (1994[25]); Price and Arnould (1999[7]); Reynolds and Beatty (1999[27]). To increase the effect of social benefit to usage intention of buying online the seller can give suggestion to the customer which product is bestseller and information related to it such as price and the product detail.

5. Research result also shown special treatment benefit increasing satisfaction. Satisfaction from the equality of the price and the product quality (related to product) is influenced by the benefit that customer get from the service quality and personalization of the product, such as motifs, color, or the type of material which is preferred by the customers.

6. The result showed special treatment benefit increasing usage intention. This result support research from Reynolds and Beatty (1999[27]), and Thorsten (2002[5]). Fast service, competitive price, special discount and other special service that not provide by the other will affect satisfaction.

7. Lastly, the result also showed satisfaction increasing usage intention. Satisfaction from the flexibility to choose batik product through online shopping may increase the intention to use another online media to search and find a new motif in batik product.

\section{SUGESSTION}

Based on the research result the effect of perceived ease of use on perceived usefulness, relational benefit and marketing outcome of online customer of batik product, showed that the overall model qualified to be accepted. Thus, the suggestion for further research are:

1. This research give finding that implementation of Customer Relationship Management Model on TAMRelational Benefit and Marketing Outcome through the fields of the three operation, which is operation, strategic and analytical. However, this research has not empirically assess the scope of those three operation in TAM-Relational Benefit and Marketing Outcome model. Thus, further research can carried out by empirical research to clarify the scope of the three operation against TAM-Relational Benefit and Marketing Outcome.

2. The further research can also compare the sales through online marketing with the conventional method or offline methods.

\section{BIBLIOGRAPHY}

[1]. Rebecca Yen, Hsiu Ju and Gwinner, Kevin P., 2003. Internet Retail Customer Loyalty : the mediating role of relational benefits, International Journal of Service Industry Management, Vol. 14 No. 5, 2003, pp. 483-500.

[2]. Hwang, Yujong and Dan J. Kim, 2007. Customer self-service systems: The Effects of perceived Web quality with service contents on enjoyment, anxiety, and e-trust, Decision Support Systems, Vol. 43, pp.746-760.

[3]. Jasman J. Ma'ruf, and Hasrati, 2004. Efektivitas Pemanfaatan Internet pada Lembaga Pendidikan dan pengembangan Profesi, Jurnal Manajemen dan Bisnis, 2 (3), Sept., 241.

[4]. Gwinner, Kevin P.,Dwayne D. Gremler, and Mary Jo Bitner, 1998. Relational Benefits in Services Industries: The Customer's Perspective, Journal of the Academy of Marketing Science, 26 (Spring), 101-114.

[5]. Thorsten, Kevin P. Gwinner and Dwayne, Gremler, 2002. Understanding Relationship Marketing Outcomes An Integration of Relational Benefits and Relationship Quality, Journal of Service Research, Volume 4, No. 3, February, $230-247$. 
[6]. Tracey S. Dagger and Timothy K. O’Brien, 2010. Does Experience Matter? Differences In Relationship Benefits, Satisfaction, Trust, Commitment And Loyalty For Novice And Experienced Service Users, European Journal of Marketing, Vol. 44 No. 9/10, 2010, pp. 1528-1552.

[7]. Price, Linda L., Eric J. Arnould and Hausman 1999. Commercial Friendships: Service Provider-Client Relationships in Context, Journal of Marketing, 63 (October), 38-56.

[8]. Umar, Husein, 2000. Riset Pemasaran, Jakarta, Gramedia.

[9]. Buttle, 2004. Customer Relationship Management : Concept and Tools, Amsterdam : Elsevier Butterworth Heinermann.

[10]. Davis FD, 1989. Perceived Usefullness, Perceived Ease of Use of Information Technology. Management Information System Quarterly, 21-37.

[11]. Lovelock, Patterson, Walker, 2001. Service Marketing: An Asia Pacific Perspective, $2^{\text {nd }}$ ed., Sidney, Prentice Hall.

[12]. Barlow, Richard G, 1992. Relationship Marketing The Ultimate in Customer Services Retail Control 60 (March): 29-37.

[13]. Hakansson, Hakan, 1982. An Interaction Approach. In International Marketing and Purchasing of Industrial Goods: An Interaction Approach. Ed. Hakan Hakansson. New York: John Wiley, 10-27.

[14]. Venkatesh, V Crosby, Kenneth R. Evans, and Deborah Cowles, 1995. Relationship Quality in Services Selling: An Interpersonal Influence Perspective, Journal of Marketing 54 (July): 68-81.

[15]. Berry, Leonard L. 1995. Relationship Marketing of Services Growing Interest, Emerging Perspectives, Journal of the Academy of Marketing Science 23 (Fall), 236-245.

[16]. Usmara, 2003. Strategi Baru Manajemen Pemasaran, PT. Amara Books, Yogyakarta.

[17]. Kotler, Philip, and Gary, Armstrong, 2004. Principle of Marketing, Prentice Hall Inc., Seventh Edition, Englewood Cliffs, New Jersey.

[18]. Dutka, Alan, 1995. AMA Handbook of Customer Satisfaction. The American Marketing Association.

[19]. Grace T.R. Lin and Chia-Chi Sun, 2009. Factors Influencing Satisfaction and Loyalty in Online Shopping: an Integrated Model, Online Information Review, Vol. 33 No. 3, pp. 458-475

[20]. Cheng, E, Lam, D and Andy Y, 2005. Adoption of Internet Banking : An Empirical Study in Hongkong, Department of Logistics, Hong Kong: The Hong Kong Polytechnic University, Hung Hom, Kowloon.

[21]. Hong, J , Thong, J and Yan, KT , 2006. Understanding continued information technology usage behavior: a comparison of three models in the context of mobile internet, Decision Support Systems, Vol. 42, pp. 1819-1834.

[22]. Zigmund, W.G., 2000. Business Research Method, (6th ed.), Forth Worth: Harcourt Inc.

[23]. Hair, Joseph F., Anderson, Raph E, Tatham, Ronal L and Black, William C. 1998. Multivariate Analysis, Fifth Edition, Prentice Halll International Inc.

[24]. Solimun, 2006. Structural Equation Modelling, LISREL, dan AMOS, Malang: Fakultas MIPA, Universitas Brawijaya, Malang.

[25]. Goodwin, Cathy, 1994. Between Friendship and Business: Communal Relationships in Service Exchanges, Working paper. University of Manitoba.

[26]. Rose, Janelle and Fogarty, Gerard, 2006. Determinants of Perceived Usefulness and Perceived of Easy of Use in The Technology Acceptance Model : Senior Consumers Adoption of Self Service Banking Technologies, Academy of World Business, Marketing \& Management Development, Conference Proceedings, Volume 2 No 10, July 2006.

[27]. Reynolds, Kristy E. and Sharon E. Beatty, 1999. Customer Benefits and Company Consequences of Customer-Salesperson Relationships in Retailing, Journal of Retailing, 75 (Spring), 11-32.

[28]. Gremler, and Kevin P. Gwinner, 2000. Customer-Employee Rapport in Service Relationships, Journal of Service Research, 3 (August), 82-104.

[29]. Buttle, 2004. Customer Relationship Management: Concept and Tools, Amsterdam : Elsevier Butterworth Heinermann.

[30]. Oliver, Richard L, 1999. "Whence Consumer Loyalty", Jounal of Marketing., Volume 63 Special Issue, p.33-44.

[31]. Kim, Changki, 2007. an Empirical Investigation into the Utilization-Based Information Technology Success Model: Integrating Task Performance and Social Influence Perspective, Journal of Information Technology, 22, pp. 152-160

[32]. Tjiptono, Fandy, 1997. Strategi Pemasaran, Penerbit Andi Offset, Yogyakarta. 